\title{
Endothelial viability of organ-cultured corneas following penetrating keratoplasty
}

\begin{abstract}
Purpose To assess endothelial integrity following corneal transplantation using human corneas stored in organ culture in the Manchester Eye Bank.

Methods A prospective study was undertaken on 24 patients who had received full-thickness corneal grafts using corneas stored in organ culture. The donor corneal endothelium was photographed prior to transplantation using light microscopy. Specular microscopy and ultrasonic pachometry were performed at 30 days ( \pm 3 days), 12 weeks ( \pm 1 week), 26 weeks ( \pm 2 weeks) and 52 weeks ( \pm 4 weeks) following corneal transplantation. The following cell parameters were measured: density, area, coefficient of variation (CV) for area, perimeter, diameter, form factor and corneal thickness.

Results One year after corneal transplantation there was a statistically significant decrease in endothelial cell density $(-39.4 \%)$, and a statistically significant increase in endothelial cell area $(+94.4 \%)$, perimeter $(+36.1 \%)$, diameter $(+57.1 \%)$ and form factor $(+5.8 \%)$.

However, no significant changes were seen in

$\mathrm{CV}$ or corneal thickness with respect to time after transplantation. (There were no significant changes in endothelial cell parameters and corneal thickness for $\mathbf{1 2}$ control subjects.)

Conclusions Endothelial cell loss occurs at an accelerated rate from corneal transplants. This highlights the need for improving corneal endothelial viability during and after storage in order to improve the chances of longer-term survival of the transplanted cornea.
\end{abstract}

C.L. Harper

M.E. Boulton

University Department of

Ophthalmology

Manchester M13 9WH, UK

B. Marcyniuk

A.B. Tullo

A.E. Ridgway

Manchester Royal Eye Hospital

Manchester M13 9WH, UK

Catherine Harper, PhD Tissue Science Laboratories Limited

Greyholme House

49 Victoria Road

Aldershot GU11 1SJ, UK

Tel: +44 (0)1252 333002

Fax: +44 (0)1252 333010

This research was supported by the Kershaw Trust, the Corneal Endowment Fund and the Northwest Regional Health Authority
Key words Corneal transplantation, Human, Endothelium, Specular microscopy, Pachometry, Organ culture

The viability of the corneal endothelium is crucial for the maintenance of corneal transparency following transplantation. ${ }^{1}$ Although the corneal endothelium has great functional reserve, a decrease in cell density below a certain limit results in corneal swelling.
C.L. HARPER, M.E. BOULTON, B. MARCYNIUK, A.B. TULLO, A.E. RIDGWAY
The minimum density of endothelial cells required to maintain the transparency of the graft is reported to be around 400-700 cells $/ \mathrm{mm}^{2}{ }^{2}$ Therefore it is accepted practice to transplant corneas with high endothelial cell counts in acknowledgement of endothelial cell loss during and after transplantation.

The Manchester Eye Bank chose organ culture at $34{ }^{\circ} \mathrm{C}$ for corneal storage because of its significant advantages over other storage techniques. ${ }^{3}$ The fate of the corneal endothelium of grafts from corneas stored in moist chamber storage at $4{ }^{\circ} \mathrm{C}$ is well documented. ${ }^{4-6}$ However, there have been few reports from the organ culture eye banks investigating the viability of organ-cultured corneas prospectively. The aim of this study was to provide a detailed investigation into the endothelial structural integrity and viability of corneas stored in organ culture before and after transplantation.

\section{Materials and methods}

The Keeler-Konan Contact Specular microscope was used to examine and photograph the central $4 \mathrm{~mm}$ of the corneal endothelium, using the posterior concentric rings for guidance. Between four and six endothelial photographs were taken per patient per visit. A Leitz Kompira Video Imagan Digitising System was used to perform computerised image analysis on the specular microscopy negatives. To randomise the selection of the sample of 50 cells from each negative a black square outline on a transparent Perspex sheet was fixed to the television monitor. Cells overlapping two sides of the square were included and those intersected by the remaining two sides were excluded. Fifty cells were measured per film as early studies revealed no significant difference between analysing 50, 100 or 200 cells per film. The following cell parameters were measured: density, area, perimeter, diameter, coefficient of variation for area $(\mathrm{CV})$, which provides a measure of percentage polymegethism [(standard deviation of individual cell areas/ mean cell area) $\times 100$ ], and form factor, which provides a measure of pleomorphism $[4 \pi \times$ area/perimeter]. ${ }^{2}$ 
To monitor the reproducibility of the operator 10 cells of a healthy male volunteer, aged 25 years at the start of the study, were measured at 2 week intervals over a 3 year period.

A Humphrey-Allergan ultrasonic pachometer (model 850) with a hand-held transducer was used to measure central corneal thickness readings as previously discussed. ${ }^{8}$

This research followed the tenets of the Declaration of Helsinki (1975). Informed consent was obtained from the subjects after the nature and possible consequences of the study were explained.

\section{Control group}

Healthy human subjects free from ocular disease, who had adequate tear film production (a minimum of $15 \mathrm{~mm}$ in 5 min using the Schirmer tear test) and were unadapted to contact lens wear, were used as controls. Ultrasonic pachometry and specular microscopy were performed on the control group at the following intervals: 0,30 days ( \pm 3 days), 12 weeks ( \pm 1 week), 26 weeks ( \pm 2 weeks) and 52 weeks ( \pm 4 weeks), and every 26 weeks thereafter over a period of 3 years. The first session was taken as time ' 0 ' to correspond with the pretransplantation photographs of the donor corneal endothelium.

\section{Grafted patients}

Patients who had full-thickness corneal grafts performed by two surgeons (A.B.T. and A.E.R.) at Manchester Royal Eye Hospital using corneas stored in organ culture in the Manchester Eye Bank were recruited over a period of 2 years. The donor corneal endothelium was photographed prior to transplantation using light microscopy. The date of the transplantation was taken as time ' 0 ' and the corneal endothelium was photographed by contact specular microscopy at the same intervals as the control group up to 1 year and in some patients every 26 weeks thereafter. Central corneal thickness was also monitored at these times following transplantation using ultrasonic pachometry.

\section{Statistical analyses}

Standard errors of the mean ( \pm SEM) are quoted after the mean unless otherwise stated. Minitab version 8.2 was used to calculate the analyses of variance and regression analysis. Standard analysis of variance was used in this study (a regression line is shown on the graphs). Although the long-term decay is exponential, the first year represents a small linear aspect of the overall exponential graph. ${ }^{1}$

\section{Results}

\section{Accuracy and reproducibility}

Accuracy and reproducibility of specular microscopy measurements demonstrated that the accuracy of the mean was $5.8 \%$ in the first 3 months and decreased to $2.7 \%$ by 12 months. ${ }^{7}$ Ultrasonic pachometry readings were highly reproducible, with a coefficient of variance of less than $1.8 \%$ throughout the experimental period. ${ }^{8}$

\section{Control group}

Twelve subjects ( 6 male, 6 female) aged between 10 and 65 years completed the study. The mean age for the 12 individuals at the beginning of the study was $39 \pm 19$ years $( \pm \mathrm{SD})$.

Within the control group there were no changes in cell density, area, perimeter, diameter, $\mathrm{CV}$, form factor or thickness over the 3 year study period $(p>0.4)$. The mean density for the group was $3216 \pm 499$ cells $/ \mathrm{mm}^{2}$ over the 3 years of the study. For all individuals, cell density remained relatively constant, with values varying by less than $2 \%$ of the mean for each individual. The mean values for cell parameters of the group over the 3 year period were: area $=307 \pm 11 \mu \mathrm{m}^{2}$; perimeter $=$ $63 \pm 12 \mu \mathrm{m}^{2}$; diameter $=19 \pm 0.1 \mu \mathrm{m}^{2}$; form factor $=$ $0.90 \pm 0.005$; and CV $=20.9 \pm 0.24 \%$. The mean corneal thickness for the group was $544 \pm 35 \mu \mathrm{m}$. However, when the data were analysed with respect to patient age it was clear that there was a significant age-related decrease in cell density (3902 to 2467 cells $/ \mathrm{mm}^{2}$, $p<0.001)$, and increase in cell area $\left(223\right.$ to $\left.390 \mu \mathrm{m}^{2}\right)$, perimeter (47 to $72 \mu \mathrm{m}$ ), diameter (17 to $21 \mu \mathrm{m}$ ), CV $(15.5 \%$ to $22 \%)$ and corneal thickness (486 to $548 \mu \mathrm{m})$ at each time interval $(p<0.001)$.

\section{Grafted patients}

Twenty-four grafted patients were recruited. The mean recipient age of the transplanted group was $66 \pm 18$ $( \pm \mathrm{SD})$ years at the beginning of the study and the mean donor age was $53 \pm 13$ ( \pm SD) years. Patients experiencing rejection episodes were excluded from the study. The diagnoses of the recipients were as follows: herpes simplex keratitis $(n=7)$, lattice dystrophy $(n=2)$, Fuchs' dystrophy $(n=7)$, bullous keratopathy $(n=4)$, keratoconus, ulcerative keratitis $(n=3)$ and decompensation due to glaucoma $(n=1)$.

Corneal endothelial cell parameters changed significantly with increasing time after transplantation (Table 1, Fig. 1). Compared with mean parameters for donor endothelial cells immediately prior to transplantation, parameters at 12 months after transplantation demonstrated a significant decrease $(p<0.001)$ in endothelial cell density $(-39.4 \%)$, and a significant increase $(p<0.001)$ in endothelial cell area $(+94.4 \%)$, perimeter $(+36: 1 \%)$, diameter $(+57.1 \%)$ and form factor $(+5.8 \%)$. The CV decreased by $27 \%$ over 12 months but this was not significant $(p>0.8)$. A $4 \%$ decrease in corneal thickness occurred between 1 month 

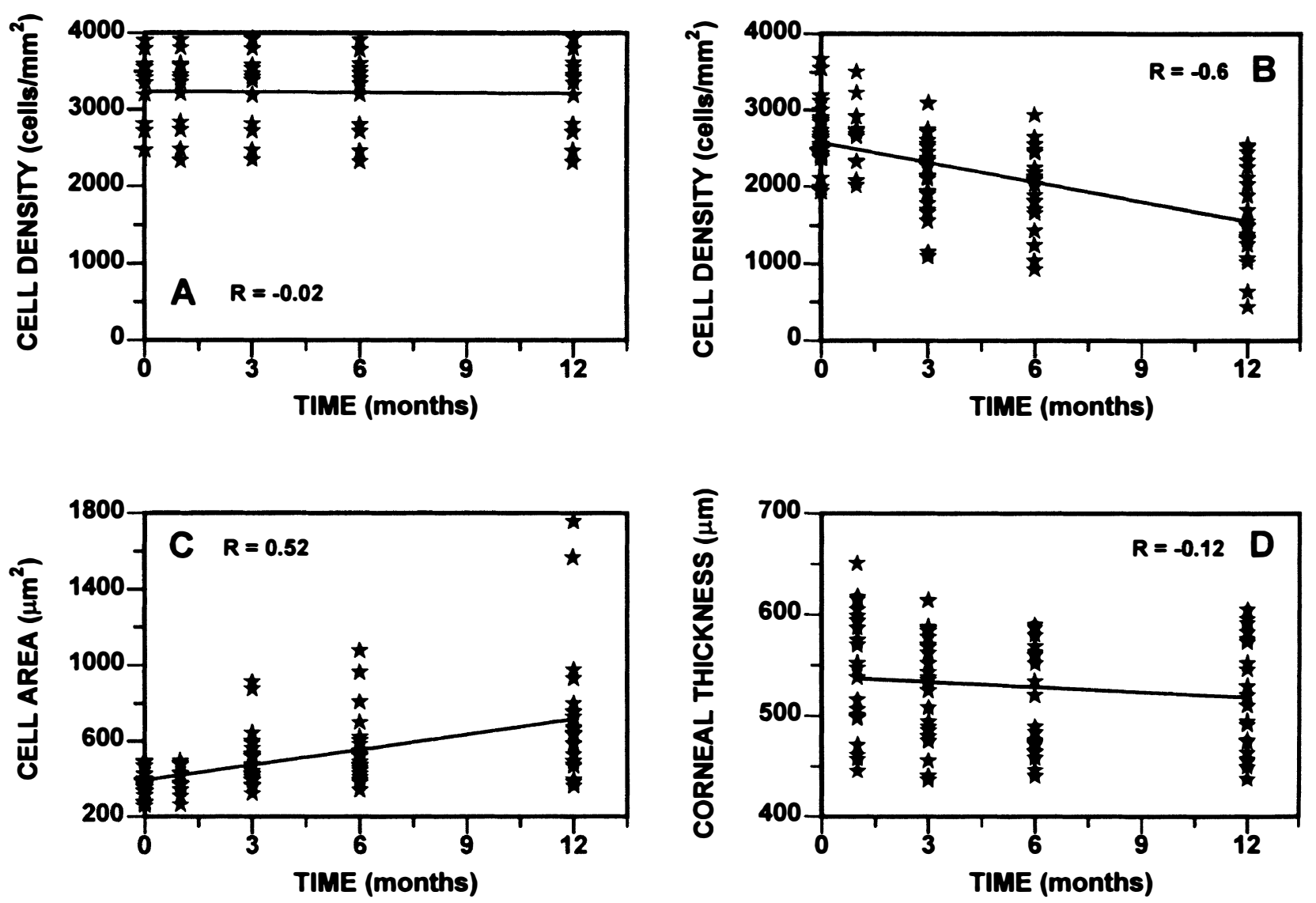

Fig. 1. Graphs demonstrating corneal endothelial cell density $(A, B)$, area $(C)$ and central corneal thickness $(D)$. $(A)$ represents healthy subjects while $(B-D)$ represent grafted patients over a 12 month period.

and 12 months after transplantation, which was not significant $(p>0.8)$. Since limited numbers of patients were analysed beyond 12 months the regression lines shown on the graphs (Fig. 1) do not include the longer time points with few values in order to avoid bias. However, the limited values at the longer time points appear to follow the post-transplantation trend for each parameter.

Table 1. Changes in corneal endothelial cell parameters and corneal thickness of 24 grafts with time after transplantation

\begin{tabular}{|c|c|c|c|c|c|c|}
\hline \multirow[b]{2}{*}{ Parameter } & \multirow[b]{2}{*}{ Pre-transplantation } & \multicolumn{4}{|c|}{ Time after transplantation (months) } & \multirow[b]{2}{*}{$p$ value } \\
\hline & & 1 & 3 & 6 & 12 & \\
\hline Density (cells $/ \mu \mathrm{m}^{2}$ ) & 2662 & 2582 & 2151 & 1992 & 1612 & $<0.001$ \\
\hline (SEM) & $(86)$ & (139) & $(192)$ & $(115)$ & $(118)$ & \\
\hline$\%$ decrease & 0 & -3 & -19.2 & -25.5 & -39.4 & \\
\hline Area $\left(\mu \mathrm{m}^{2}\right)$ & 377 & 395 & 507 & 561 & 620 & $<0.001$ \\
\hline (SEM) & $(58)$ & (71) & $(145)$ & $(184)$ & $(400)$ & \\
\hline$\%$ increase & 0 & 4.8 & 34.2 & 48.8 & 94.4 & \\
\hline Perimeter $(\mu \mathrm{m})$ & 72 & 74 & 83 & 88 & 98 & $<0.001$ \\
\hline (SEM) & $(0.3)$ & $(0.6)$ & $(0.5)$ & $(0.6)$ & $(1.0)$ & \\
\hline$\%$ increase & 0 & 2.8 & 15.3 & 22.2 & 36.1 & \\
\hline Diameter $(\mu \mathrm{m})$ & 21 & 24 & 27 & 28 & 33 & $<0.001$ \\
\hline$(\mathrm{SEM})$ & $(0.1)$ & $(0.2)$ & $(0.2)$ & $(0.2)$ & $(0.32)$ & \\
\hline$\%$ increase & 0 & 14.3 & 28.6 & 33.3 & 57.1 & \\
\hline Form factor & 0.86 & 0.89 & 0.90 & 0.90 & 0.91 & $<0.001$ \\
\hline$(\mathrm{SEM})$ & $\left(6 \times 10^{-4}\right)$ & $\left(16 \times 10^{-4}\right)$ & $\left(8 \times 10^{-4}\right)$ & $\left(7 \times 10^{-4}\right)$ & $\left(4 \times 10^{-4}\right)$ & \\
\hline$\%$ increase & 0 & 3.5 & 4.7 & 4.7 & 5.8 & \\
\hline $\mathrm{CV}(\%)$ & 27.0 & 21.4 & 23.0 & 22.0 & 19.7 & 0.846 \\
\hline (SEM) & $(0.2)$ & $(0.3)$ & $(0.2)$ & $(0.2)$ & $(0.2)$ & \\
\hline$\%$ decrease & 0 & 20.7 & 14.8 & 18.5 & 27.0 & \\
\hline thickness & a & 544 & 530 & 520 & 522 & 0.812 \\
\hline$(\mathrm{SEM})$ & & $(2.4)$ & $(2.2)$ & $(2.0)$ & (2.3) & \\
\hline$\%$ decrease & & 0 & 2.5 & 4.4 & 4.0 & \\
\hline
\end{tabular}

${ }^{\mathrm{a}}$ No pre-transplantation reading. 


\section{Discussion}

Grafted patients demonstrated an accelerated decline in corneal endothelial cell density with time after transplantation that is in agreement with previous studies. ${ }^{9-12}$ Endothelial cell perimeter and diameter increased significantly following surgery and were closely correlated with the relatively uniform increase in endothelial cell area. This decline must reflect loss due to transplantation since there were no significant age-related changes in normal corneal endothelial cell density, parameter, diameter, form factor, $\mathrm{CV}$ or central corneal thickness over the 3 years of the study for the control group. Failure to detect yearly change in endothelial cell density may reflect the small sample size, since other studies have reported that the decline in endothelial cell density of the healthy human cornea due to aging is approximately $0.5 \%$ per year. ${ }^{13-15}$ Thus this cannot account for $39.4 \%$ of cell loss from the transplanted corneal endothelium 1 year after transplantation.

The Bristol Eye Bank reported a decline in endothelial cell density in patients 1 year after transplantation using organ culture at $34{ }^{\circ} \mathrm{C} .{ }^{11}$ The mean pre-operative donor density for the Bristol group was 2379 cells $/ \mathrm{mm}^{2}$, which is lower than the value of 2662 cells $/ \mathrm{mm}^{2}$ obtained in this study. At 1 year after transplantation Bristol corneas had decreased in density by $18.4 \%$ to 1946 cells $/ \mathrm{mm}^{2}$, compared with a higher decrease of $39.4 \%$ to 1612 cells $/ \mathrm{mm}^{2}$ in Manchester grafts. A decrease of $30.2 \%$ was reported by Rijneveld et al. ${ }^{9}$ of the Amsterdam Eye Bank between 6 and 24 months after transplantation also using organ-cultured corneas, and a corneal thickness measurement of $565 \pm 51 \mu \mathrm{m}$ was reported which compares with the $522 \pm 55 \mu \mathrm{m}$ at 1 year in this study. One year after transplantation a decline in endothelial cell density was observed with increasing donor age, which is in agreement with previous studies. ${ }^{12,16,17}$

Accelerated endothelial cell loss has also been observed with other methods of corneal storage. Moist chamber stored corneas lost $33.6 \%$ endothelial cells 12 months after transplantation. ${ }^{5}$ A higher value of $48 \%$ was reported by Obata et al. ${ }^{18}$ after 1 year. Corneas stored in MK medium have produced rates of endothelial cell loss of $25 \%{ }^{19}$ and $52 \%{ }^{20}$ at 1 year after transplantation. However, making comparisons between different eye banks only gives an indication of endothelial cell loss. It is important to note that factors such as storage temperature, surgeon and cell counting method vary between different studies. Transplantation of the human cornea, whatever the storage method used, appears to result in an accelerated and exponential loss of endothelial cells. From this it is evident that as yet there is no ideal method of corneal storage for donor corneas prior to transplantation, although some factors such as donor age are more influential than others on the suitability for transplantation. ${ }^{21}$

The cause and mechanism of the rapid endothelial cell loss from the central corneal transplant following surgery is still unknown. Subclinical immunological allograft rejection might occur that could adversely affect the corneal endothelium without becoming clinically apparent. However, no evidence of this has been reported in the literature. ${ }^{12}$ On the contrary, a high level of endothelial cell loss was reported in a case of a human autograft, ${ }^{22}$ where immunological rejection cannot occur. Damage sustained by the peripheral host corneal endothelium, e.g. pseudophakic bullous keratopathy, could result in subnormal peripheral endothelial cell density which in turn could induce the migration of grafted endothelium from the central graft to the periphery and onto the host corneal surface. ${ }^{23}$ In this case less migration would be expected from the graft to the peripheral host cornea in eyes with higher endothelial cell densities such as keratoconus. Corneal endothelial cells can also migrate in the other direction, i.e. from the host endothelium on the graft surface. ${ }^{24}$ Bourne et al. ${ }^{12}$ reported no difference in the rate of endothelial cell loss from eyes transplanted for the diagnosis of keratoconus or Fuchs' endothelial dystrophy. However, Obata et al. ${ }^{18}$ reported a lower rate of endothelial cell loss in patients grafted for keratoconus compared with those grafted for bullous keratopathy. The fact that endothelial cell attrition occurs with ageing in the healthy cornea suggests that endothelial cell loss from the central endothelium of the transplanted cornea is a combination of cell redistribution and cell death.

It is well documented that surrounding endothelial cells spread to compensate for cell loss. However, the mechanism of cell death is not understood. Endothelial cell attrition could result from endothelial cells detaching from Descemet's membrane leaving a denuded region that is quickly covered by adjacent endothelial cells. Alternatively, dead and dying cells could be phagocytosed by surrounding cells as they spread, which would maintain an intact endothelial barrier. The decline in endothelial cell density with age reported here is paralleled by an overall decline in metabolic activity. ${ }^{25}$ It is possible that metabolic stress causes certain cells to dysfunction with time. The deterioration of human corneal endothelium associated with organ culture ${ }^{19}$ may be attributed to apoptotic cell death. ${ }^{26}$ Manipulating culture medium to suppress endothelial apoptosis offers the possibility of a higher endothelial cell density better able to withstand whatever mechanism currently leads to substantial post-transplantation cell loss.

These investigations not only document the decline in endothelial cell density of the transplanted human corneal endothelium, but also provide data on changes in endothelial cell parameters and corneal thickness. Further research is required to establish whether factors can be manipulated during storage to reduce cell loss during and after culture to offer improved chances of longer-term survival of the transplanted cornea.

\section{References}

1. Bourne WM. One year observation of transplanted human corneal endothelium. Ophthalmology 1980;8:673-9.

2. Bourne WM, Kaufman HE. The endothelium of clear corneal transplants. Arch Ophthalmol 1976;94:1730-2. 
3. Pels E, Schuchard Y. Organ-culture preservation of human corneas. Doc Ophthalmol 1983;56:147-53.

4. Lass JH, Reinhart WJ, Bruner WE, Krachmer ML, Lomeo $\mathrm{MD}$, Morgan KM, et al. Comparison of corneal storage in $\mathrm{K}$ sol and chondroitin sulfate corneal storage medium in human corneal transplantation. Ophthalmology 1989;96:688-97.

5. Culbertson WW, Abbott RL, Forster RK. Endothelial cell loss in penetrating keratoplasty. Ophthalmology 1982;89:600-4.

6. Shimazaki J, Yamada M, Tsubota K. Corneal transplantation with donor corneas stored in moist chamber and chondroitin sulfate-containing medium. Cornea 1993;12:104-8.

7. Harper CL. The viability of the human corneal endothelium in vivo and in vitro [thesis]. University of Manchester, UK, 1995.

8. Harper CL, Boulton ME, Bennett D, Marcyniuk B, JarvisEvans JH, Tullo AB, Ridgway AE. Diurnal variations in human corneal thickness. Br J Ophthalmol 1996;80:1068-72.

9. Rijneveld WJ, Beekhuis WH, van Rij G, Drieb B, Pels E. Clinical comparison of grafts stored in McCarey-Kaufman medium at $4{ }^{\circ} \mathrm{C}$ and corneal organ culture at $31^{\circ} \mathrm{C}$. Arch Ophthalmol 1992;110:203-5.

10. Redmond RM, Armitage WJ, Whittle J, Moss SJ, Easty DL. Long-term survival of endothelium following transplantation of corneas stored by organ-culture. $\mathrm{Br} \mathrm{J}$ Ophthalmol 1992;76:479-81.

11. Redbrake C, Becker J, Salle S, Stollenwerk R, Reim M. The influence of the cause of death and age on human corneal metabolism. Invest Ophthalmol Vis Sci 1994;35:3553-6.

12. Bourne WM, Hodge DO, Nelson LR. Corneal endothelium five years after transplantation. Am J Ophthalmol 1994:118:185-96.

13. Cheng H, Jacobs PM, McPherson K, Noble MJ. Precision of cell density estimates and endothelial cell loss with age. Arch Ophthalmol 1985;103:1478-81.

14. Werblin TP. Long-term endothelial cell loss following phacoemulsification: model for evaluating endothelial cell loss after intraocular surgery. Refract Corneal Surg 1993;9:29-35.
15. Yee RW, Matsuda M, Schultz RO, Edelhauser HF. Changes in the normal endothelial cell pattern as a function of age. Curr Eye Res 1985;4:671-8

16. Musch DC, Meyer RF, Sugar A. Predictive factors for endothelial cell loss after penetrating keratoplasty. Arch Ophthalmol 1993;111:80-3.

17. Bergmann B, Bohnke M, Winter R, Draeger J. Entwinklung der Endotheldichte nach perforierender Keratoplastik. Fortschr Ophthalmol 1991;88:262-5.

18. Obata H, Ishida K, Murao M, Miyata K, Sawa M. Corneal endothelial cell damage in penetrating keratoplasty. Jpn J Ophthalmol 1991;35:411-6.

19. Bourne WM. Chronic endothelial cell loss in transplanted corneas. Cornea 1983;2:289-94.

20. Bazard MC, Tankosic P, Kohler F, Berrod JP, Raspiller A. Morphometrie endotheliale et keratoplastie perforantes. J Fr Ophtalmol 1988;11:261-8.

21. Armitage WJ, Easty DL. Factors influencing suitability of organ-cultured corneas for transplantation. Invest Ophthalmol Vis Sci 1997;38:16-24.

22. Matsuda M, Manabe R. The corneal endothelium following autokeratoplasty: a case report. Acta Ophthalmol (Copenh) 1988;66:54-6.

23. Bourne WM. Morphologic and functional evaluation of the endothelium of transplanted human corneas. Trans Am Ophthalmol Soc 1983;81:403-50.

24. Bourne WH. Penetrating keratoplasty with fresh and cryopreserved corneas: donor endothelial cell survival in primates. Arch Ophthalmol 1978;96:1073-4.

25. Lass JH, Greiner JV, Merchant TE, Glonek T. The effects of age on the phosphatic metabolites of the human cornea. Cornea 1995;14:89-94.

26. Albon J, Tullo AB, Boulton ME. Apoptosis in the endothelium of organ cultured human corneas. Invest Ophthalmol Vis Sci 1997;38:S731. 